\title{
KRITICKÁ ANALÝZA METODOLOGICKÝCH KONCEPCÍ SYMBOLICKÉHO INTERAKCIONISMU A FENOMENOLOGICKÉ SOCIOLOGIE
}

Doc. PhDr. EDUARD-URBÁNEK, CSc.

Po dru hé světové válce převládaly'nesporně v americké sociologii dva základní směry: byla to empirická výzkumná sociologie amerického typu a amerického ražení s určitými vlastními zásadami i metodami a způsobem praktického provozu a strukturní funkcionalismus jako pokus o velkou systematickou teorii. Tato strukturně funkcionální velká teorie byla současně také učením o určitých základních metodologických přístupech ke zkoumání a $\mathrm{k}$ výkladu společenské reality. Nesporný fakt převládání uvedených směrů však neměl být základem podceňování nebo ignorování jiných dosti významných a z hlediska vlivu nezanédbatelných škol a směrů americké sociologie. Od konce třicátých let se formuje a vyvíjí a po druhé světové válce vedle a často i proti empirické americké sociologii i proti americkému strukturnímu funkcionalismu prosazuje specifický produkt amerického společenského i myšlenkového vývoje - symbolický interakcionismus. Tento symbolický interakcionismus byl podobně jako strukturní funkcionalismus a americká, $v$ podstatě utilitárně a komerčně založená empirická výzkumná sociologie, vysloveně americkým produktem. Zejména je pro symbolický interakcionismus podstatná jeho genetická souvislost $\mathrm{s}$ jedinou původní americkou filozofií, s americkým pragmatismem. Když však říkáme, že tyto tři směry jsou především a hlavně produktem vývoje amerického společenského a myšlenkového vývoje, nechceme tím říci, že v určitých konkrétních a dílčích souvislostech však tyto tři původní americké sociologické směry nečerpaly vůbec $\mathrm{z}$ různých evropských filozofických nebo sociologických směrů.

Jistě je v americké empirické sociologii patrný určitý vliv britského filozofického empirismu a senzualiasmu, daly by se vystopovat dílči vlivy neopozitivistických koncepcí. Počáteční fáze konstituování Parsonsova strukturního funkcionalismu jsou zcela jasně poznamenány vlivy evropské sociologické teoretické tradice (M. Weber, E. Durkheim, V. Pareto) i britského antropologického funkcionalismu. Méně však je známo, že i typicky americká filozofie - prag- 
matismus - má určité souvislosti s německou filozofií a zvláště pak s německou idealistickou filozofií. Jde o souvislost věcnou, obsahovou i personální. Německý filozofický idealismus měl vliv na zakladatele pragmatismu Ch. S. Peirce, na W. Jamese a J. Deweye. Tato souvislost je pak patrna i u významných představitelů té linie sociální psychologie a sociologie, kteří v USA vyšli z pragmatické filozofie a stali se zakladateli školy, která později dostala název symbolický interakcionismus (napríklad u W. I. Thomase, nebo hlavně u G. H. Meada).

Základní kritické hodnocení a zařazení filozofie pragmatismu podal Lenin ve svém Materialismu a empiriokriticismu. ${ }^{1}$ ) Ale Lenin je také marxistou, který zdůraznil, že idealismus (a pragmatismus je přes všechny své odstíny $\mathrm{v}$ podstatě filozofií idealistickou) je pouze nesmyslem $\mathrm{z}$ hlediska materialismu hrubého, prostého, metafyzického. To je důležitý metodologický pokyn, který je třeba vždy při konkrétní kritické analýze uplatnit. Navíc Lenin si nekladl a ani neřešil otázku o celkovém významu pragmatismu i jeho jednotlivých představitelů ve všech oblastech, $v$ nichž se představitelé amerického pragmatismu angažovali.

Ke zvláštnostem amerického pragmatismu a jeho jednotlivých představitelů patři i to, že kromě filozofie pěstovali všichni v rámci své celkové filozofické koncepce i konkrétní vědecké disciplíny. Peirce byl nejen filozofem, ale i matematikem, logikem kromě zájmu o další vědy, jako je astronomie, chemie. James je pokládán za jednoho z významných představitelů psychologické vědy. Dewey aplikoval své koncepce i v oblasti pedagogiky. At' již přijmeme ten názor, že jejich určité vlivné postavení v konkrétních vědách vyplývalo z přednosti pragmatické filozofie, nebo ten názor, že byli významnými logiky, psychology nebo pedagogy navzdory svým pragmatickým filozofickým východiskům, zůstává nesporným faktem jejich významné místo $\mathrm{v}$ rámci těchto uvedených disciplín. U Peirce je ještě zdůrazněn jeho přínos ve sféře semiotiky, matematické a symbolické logiky. James byl nesporně jako pragmaticky orientovaný psycholog autorem, který ovlivnil formování počátečních koncepcí sociálních psychologů chicagské školy. Kritické, ale současně i částečně pozitivní hodnocení významu a vlivu čelných amerických pragmatistů podávají sovětští autoři ve své práci „Současná buržoazní filozofie“. Zde se mluví o Peircem jako o „významném americkém vědci“, o Jamesovi jako o „vynikajícím americkém psychologovi“, Peirce „razil nové cesty ve vědě“, u Deweyho se zdůrazňuje „stabilní soustředění zájmu na sociální problematiku“..2)

Americký pragmatismus byl totiž odbornými zájmy svých hlavních představitelů $\mathrm{v}$ rámci bužoazní společenské vědy do určité míry inspirativním směrem

1) Viz V. I. Lenin: Spisy sv. 14. Praha 1957, s. 361.

$\left.{ }^{2}\right)$ Viz Kolektiv: Současná buržoazní filozofie. Praha 1978, zvláště pak str. 206, 208 a 242. 
pro rozvíjení některých specifických a speciálních problémů vědeckého poznání a ovlivnil i další vývoj některých sociálních psychologů a sociologů, kteří z něho vycházeli. Určitým zdrojem, na který mohli navazovat, byly právě prvky idealistického a tím částečně i dialektického myšlení, v návaznosti na ně v rámci symbolického interakcionismu byla rozvíjena problematika osobnosti, sociálního já a zvláště pak teorie role. Velmi zajímavá je i určitá spřízněnost mezi nejvýznamnějším představitelem fenomenologické filozofie a sociologie v USA, který přinesl a přenesl do Spojených států jednak Husserlovu fenomenologii, jednák prvky koncepce Maxe Webera o smyslu lidského jednání a o konstrukci ideálních typů - A. Schützem a W. Jamesem. A. Schütz se př́ímo v době svého amerického působení odvolává na souvislost některých husserlovských a svých koncepcí vědomí s Jamesovým pojetím vědomí jako proudu vědomí.

Americká pragmatistická filozofie, která je ve svém základním zaměření idealistická, a to ve smyslu subjektivního idealismu nadhodila, pokoušela se řešit a ve zkreslené a deformované podobě i řešila řadu významných otázek, které byly nadhozeny již v německé idealistické filozofii a sama k nim na základě specifických ekonomických sociálních a třídních poměrů v USA přidala své určité dílčí interpretace a teze. I americký pragmatismus jako idealistická filozofie se svým způsobem, často velmi zvláštními a klikatými cestami bliží k reálným problémům a otázkám. Jde o problematiku aktivity lidského vědomí, o aktivní vztah osobnosti ke skutečnosti v reálném konání (zkreslené a idealistické pojetí praxe a činnosti), o otázky metody vědeckého poznání. Jiným problémem, který pragmatismus nadhodil, a tím vlastně v americkém myšlení zavedl, je problém významu a smyslu nebo vztah poznávání a hodnocení a hodnot. To jsou nesporně problémy, které také pragmatismus spojují s německou idealistickou filozofií, s jejími slabými, ale i podnětnými a silnějšími stránkami.

Všechny uvedené problémy často zasuté a zakryté křivým pojetím idealistické interpretace se mohly stát $\mathrm{v}$ souvislosti s dalši etapou vývoje amerických společenských věd i v souvislosti s aktivitou autorů, kteří byli orientováni na sociální problematiku, základem dalšího vývoje a rozvíjení teoretických a metodologických koncepcí. To se týká zvláště již uvedených představitelů americké sociální psychologie (s přesahujícími vlivy na oblast sociologie) W. I. Thomase a G. H. Meada. Navíc je ještě třeba podtrhnout tu skutečnost, že centrum rozvíjení pragmatické filozofie a později i sociální psychologie a sociologie byla Chicagská univerzita. V této souvislosti se mluví rovněž o chicagské sociologické škole. Přesnější by bylo mluvit o chicagské sociologické a sociálně psychologické škole. Navíc lze u všech jejich představitelů v té či oné míře zaznamenat vliv pragmatické koncepce, mnozí z představitelů uvedené školy dokonce studovali na německým univerzitách (Thomas, Mead, ostatně v Německu studoval i James). Z hlediska našeho zájmu především o metologickou problematiku 
au torů, kteří zakládají směr symbolického interakcionismu, nebo v něm pokračují, je účelné začít alespoň stručnou analýzou metodologických východisek W. I. Thomase.

\section{SYMBOLICKÝ INTERAKCIONISMUS}

\section{Základní metodologická východiska} V. I. Thom a se

W. I. Thomas (1863-1947) je všeobecně uváděn poměrně jen v úzké souvislosti s dílem, jež rozpracoval spolu s polsko-americkým sociologem F. Znanieckim. Jde o proslulé dílo v pěti svazcích $s$ názvem „Polský sedlák v Evropě a Americe“. Toto dílo bývá velmi často, a to s neuvěřitelnou tvrdošíjností označováno za jeden z počátků empirické sociologie a empirických sociologických výzkumů. Empirické sociologické výzkumy prováděli v Evropě již v 19. století mnozí bužoazní sociologové, takže známý představitel určité varianty neopozitivistické orientace $\mathrm{v}$ sociologii P. Lazarsfeld tvrdí, že domovem empirické výzkumné sociologie je Evropa. Svým způsobem má pravdu. Empirické výzkumné analýzy realizoval přece $\mathrm{F}$. Tönnies, částečnĕ dokonce i $\mathrm{M}$. Weber, dále pak výrazně Ch. Booth a $\mathrm{F}$. Le Play. Ale např́klad Tönnies prováděl sociologické empirické výzkumy zcela jednoznačně na základě svých obecných filozofických a obecných metodologických předpokladů. Totéž dělal nakonec i W. I. Thomas. Považovat Thomase a Znanièckého za průkopníky a první představitele omezené americké empirické sociologie je naprosto nesprávné a může se to dít jen ze zásadního nepochopení, nebo také z neznalosti jejich celkového díla. Nakonec spojení obecných filozofických, teoretických a metodologických východisek se zkoumáním ohromného empirického materiálu je naprosto běžné u klasiků marxismu-leninismu. Nelze ztotožňovat zkoumání empirického rozsáhlého materiálu na základě obecných filozofických teoretických a metodologických východisek, jak to bylo běžné u zakladatelů marxismu a u Lenina, nebo také i u významných představitelů buržoazní sociologie poslední třetiny 19. století a počátku 20 . století s americkou omezenou empirickou sociologii, jež vznikla a rozvíjela se především na základě komerčním a v pojetí úzké instrumentální metodologie. $\mathrm{V}$ tomto smyslu není a nemůže být ani Thomas, ani Znaniecki uváděn jako klasický představitèl této omezené, empirické americké sociologie se všemi jejími základními spornými, neuspokojivými metodologickými a teoretickými (často i nevyslovenými) předpoklady.

Thomas původně vystudoval jazyky a také jazyky učil. Při studiích v Evropě a zvláště pak v Německu se seznámil s německou psychologií (Lazarus, Steint- 
hal) a osvojil si v určité mirre některé filozofické myšlenky německé idealistické filozofie. Jeho pozdější činnost $\mathrm{v}$ oblasti sociologie a sociální psychologie má své ne vždy plně vyslovené specifické metodologické předpoklady, jindy naopak Thomas své některé metodologické výchozi myšlenky výslovně zdůraznuje. Ve svém hlavním díle, které vytvořil spolu se Znanieckým, ale i ve svých pracích, které vypracoval samostatně, Thomas jasně vystupuje $\mathrm{z}$ hlediska metodologie jako odpůrce naturalistické redukce společenských jevů. Společnost zkoumá z hlediska vzájemného působení a ovlivňování společnosti a osobnosti, role osobnosti je u něj vždy interpretována jako aktivita v rámci velmi typických pojmù, které najdeme i u Znanieckého. Jde o pojmy pozornost, později postoj, význam, hodnota. Žádný jednostranný a typický predstavitel empirické sociologie nebude pracovat s kategoriemi postoje, významu a hodnoty, interpretovanými spíše v duchovědní německé tradici. Lze jistě vést diskuse o tom, že duchovědní ba přimo neokantiánská tradice analýzy významů, hodnot je spíše akcentována Znanieckým, ale i tak je nesporné, že i Thomas s nimi pracuje ve svých samostatných pracích. $O$ tom se lze naprríklad přesvědčit i z výběru studií a částí některých jeho samostatných prací. ${ }^{3}$ ) Ostatně i se Znanieckým rozpracovaná metoda studia dokumentů (deníky, korespondence) odpovídá tomu, co Thomas nazýval individuálními životními záznamy a co bylo později rozpracováno ne bez vlivu Thomase jako takzvaný biografický př́stup či výklad při studiu vztahů jedinec, osobnost a společnost, společenský řád.

Ale i další důležitý pojem či koncept Thomasovy sociologie a sociální psychologie definice situace je něčím víc než jenom pouhým popisem nebo zjištěním objektivních a subjektivních předpokladů interakce, do níž vstupují jednotlivci ve svém sociálním chování. Thomas výslovně brojí proti behaviorismu při výkladu sociální osobnosti a přimo říká, že „chování individua jako sociální osobnosti není vědecky redukovatelné na smyslově pozorované hnutí a nemůže být vysvětleno na základě př́mé zkušenosti pozorujícího psychologa“. ${ }^{4}$ ) Thomas proto jednoznačně zdůrazňuje kategorii smyslu a významu, která je důležitá pro pochopení interakční situace. Jde však ještě dál a zdůrazňuje, že prostřednictvím významů, který lidé dávají situaci, nebo které pro ně situace má, definují tuto situaci ve shodě se svými postoji, svými hodnotami. Zde Thomas rozpracoval svou dodnes vlivnou koncepci definice situace, která může být jen stěží a dokonce $s$ určitým myšlenkovým násilím spojována s omezeným přistupem výzkumné empirické sociologie. Podle Thomasovy interpretace situace je definována jako reálná, je-li reálná ve svých důsledcích. To znamená, že jednání lidí není ovlivněno jen vnějšími objektivními podmínkami, ale těmi formami

$\left.{ }^{3}\right)$ W. Thomas: On Social Organization and Social Personality. Chicago, Londýn 1966.

$\left.{ }^{4}\right)$ W. Thomas: On Social Organization and Social Personality. Chicago, Londýn 1966, s. 25. 
vědomí, tj. postoji, hodnotami a významy, s nimiž danou interakční situaci definují a interpretuji. Tak např́klad, jestliže skupina definuje $v$ souladu se svými postoji a hodnotovými interpretacemi svůj stav či situaci jako ohroženou vnějším nepřítelem, může jednat úplně ve shodě s touto definicí situace, i když zvenčí ohrožena není, nebo ohrožení je daleko menší, než jak to sama hodnotí. Je třeba zdůraznit, že pojem situace a pak i Thomasova definice situace byla převzata nejvýznamnějšími představiteli symbolického interakcionismu a v širším kontextu např́klad i významným teoretikem sociálního konfliktu americkým sociologem L. Coserem pro rozlišování realistického a nerealistického konfliktu. ${ }^{5}$ )

W. I. Thomas je tak jedním z významných představitelů americké sociální psychologie a sociologie, který patří $\mathrm{k}$ vlivné chicagské škole a zakládá tradici směru takzvaného symbolického interakcionismu. Není to a nemůže být v žádném př́padě představitel pozdější omezené výzkumné americké empirické sociologie s jejím důrazem na takzvané exaktní metody a techniky sociologického výzkumu s výrazným odporem proti všem takz vaným subjektivním či subjektivistickým př́stupům. Thomas navázal na některé prvky pragmatické filozofie, zvláště pak na Jamese, pod vlivem německé psychologie a filozofie i jako sociologický badatel tyto pragmatické inspirace modifikoval po svém a samozřejmě také pod vlivem spolupráce $s \mathrm{~F}$. Znanieckým. Ten byl výslovně vychován ve filozofické duchovní až neokantiánké tradici s jejím důrazèm na hodnoty a významy, které spojují jednající se svým společenským jednáním. Proto také $\mathrm{u}$ Thomase nacházíme $\mathrm{v}$ rámci jeho specifické terminologie i $\mathrm{v}$ jeho výzkumných pracích akcent na určité vzájemné působení (zárodečně dialektické), ovlivňování společnosti a individua, $s$ důrazem na aktivitu individua ve vztahu ke společnosti, $\mathrm{k}$ objektivním situacím. To jsou jeho termíny pozornost, postoj, přání, hodnoty a významy-i definice situace. $Z$ toho také vyplývá implicitní odpor Thomase vůči behavioristické redukci chování na instinkty či vnější popudy. Odtud jeho zdůrazňování aktivity sociální osobnosti i pokus o určitou elementární dialektiku vztahu prŕrodního a sociálního při interpretaci osobnosti (zejména prri analýze vztahu temperamentu a charakteru). Odtud také zásadní metodologická preference studia osobních dokumentů, jako jsou deníky či korespondence, které jsou podle Thomase důležitými individuálními životními záznamy pro určení abstraktních sociálních zákonů. Později uvidíme, jak tyto specifické metodologické přístupy ovlivnily rozvoj dalších představitelů symbolického interakcionismu, kteří čerpali z Thomasova díla, ale současně také z díla dalšího vlivného představitele chicagské sociologické školy G. H. Meada. Mead

$\left.{ }^{5}\right)$ Viz L. A. Coser: Continuities in the Study of Social Conflict. New York, The Free Press, Londýn 1968. 
přednášel filozofii a sociální psychologii v Chicagu a nepodílel se na rozdíl od Thomase na aplikaci svých východisek a předpokladů $\mathrm{v}$ některé výzkumné práci, která by interpretovala empirický materiál. Zde tedy nedochází $\mathrm{k}$ nejasnostem a Mead není zařazován mezi průkopníky či první představitele americké výzkumné empirické sociologie. Jeho hlavní výchozí teoretické a metodologické přístupy jsou však zcela nesporně podobné či příbuzné s koncepcemi W. I. Thomase.

2. Metodologické koncepce G. H. Me ada

G. H. Mead (1863-1931) vycházel podobně jako Thomas z vlivů amerického pragmatismu, i když ho bezprostředně ovlivnil především jeho učitel J. Royce svou idealistickou teorií osobnosti. Mead znal dosti podrobně i práce evropských autorů francouzských. Jeho metodologickou koncepci výkladu sociálıí osobnosti ovlivnil známý Charles Horton Cooley, který však je u nás uváděn především v souvislosti s koncepcí primární skupiny. I zde se tvrdošíjně a v rozporu s fakty připisuje Cooleymu i koncepce sekundárních skupin. Tu však v jeho díle nenajdeme. Avšak z hlediska vlivu Cooleyho na G. H. Meada daleko více pưsobila jeho teorie „zrcadlového já“ (looking-glass self). Cooley v ní specifickým způsobem přepracoval idealistické pojetí osobnosti, které znal od Royce a téź i od Jamese. Velmi jednoduše lze tuto koncepci sociálního zrcadlového já vyložit takto: Jako vidíme v zrcadle svou tvář nebo postavu a oblečení, tak nacházíme svou sociální podobu v zrcadle druhých, jak o nás smýšlí, jak nás interpretují ve svém vědomí druzí. Zde bychom mohli dokonce $s$ určitou aktualizací podotknout, že Cooley ve svém pojetí zrcadlového já a v širším pojetí i skupiny a společnosti anticipuje husserlovské pojetí sociální reality jako intersubjektivity. Společnost je pro Cooleyho něco, co existuje v mém myšlení jako kontakt a vzájemný vliv určitých idejí a představ, které mají ve svém vědomí i druzí. Společnost je závislá na vědomí druhých a na mém vlastním, i na vzájemné komunikaci s druhými.

Bez ohledu na to, že jde o jen velmi stručné vyjádření souvislosti Cooleyho koncepce zrcadlového já a skupiny i společnosti s Meadovými koncepcemi, lze zcela jasně už u Cooleyho najít metodologické př́stupy, které jsou rozvinuty později u Meada. Byly tu samozřejmě i další zprostředkující vlivy. I Mead studoval v Německu, a to dokonce u známého Wundta. Př́mo v USA reagoval na vlivný psychologický behaviorismus, který reprezentoval J. B. Watson. Mead vychází při rozpracování svých vlastních metodologických a teoretických př́istupů z určité kritiky těchto uvedených směrů. Wundtovi vytýká, že vychází z předpokladu, že myšlení existuje předem jako zdroj vysvětlení duševních jevů. Psychologický behaviorismus nenís to vysvětlit specifiku duševních jevů. Vlast- 
ní pragmatismus a jeho hlavní představitelé James a Dewey nebyli s to ukázat mechanismus vzniku myšlení a sociálního já.

Mead nazýval své původní přístupy k lidskému chování sociální behaviorismus. Jeho klíčová teze spočívá $\mathrm{v}$ tom, že myšlení i sociální já je společensky determinováno, že vzniká $\mathrm{v}$ procesu sociální interakce a komunikace. Mead podobně jako Thomas tedy kritizuje ryze naturalistické, biologizující pojetí myšlení i sociálního já a př́mo kọnstatuje, že zkoumání já a myšlení nemůže být řešeno čistě objektivní psychologií, která studuje chování tak, jak je dostupné pozorovateli. Současně se Mead snaží i metodologicky překonat původně ryze idealistické koncepce já, které byly rozvinuty v díle Royce a Jamese.

Svéráznou stránkou činnosti Meada jako zakladatelské osobnosti symbolického interakcionismu je jeho působení na studenty, na filozofii, sociální psychologii a později i na sociologii. Mead nikdy za svého života nevydal nějakou systematickou větší monografii, jeho dílo - to jsou převážně přednášky na univerzitě, př́ipadně dílčí stati a studie. Teprve po jeho smrti vydávali Meadovi žáci a stoupenci jeho díla, dokonce př́mo i ze záznamu přednášek. Významným editorem Meadova díla byl známý odborník $\mathrm{v}$ oblasti sémiotiky a teorie znaků Charles W. Morris. Jde zejména o stěžejní Meadovo dílo Mind, Self and Society (1934) a The Philosophy of the Present (1938). Z dalších děl, které edičně obstarali jiní autoři, je to The Philosophy of Act (1932) a Movements of Thought in the Nineteenth Century (1936).

$\mathrm{Z}$ posmrtně vydaných děl je zřejmé, že mají filozofické zaměření, ovšem specifikum Meadova působení je v tom, že svými koncepcemi ovlivnil výrazně americkou sociální psychologii a sociologii. Po druhé světové válce, kdy se již zformovala dosti početná skupina Meadových stoupenců ve směru symbolického interakcionismu, jeden $\mathrm{z}$ jejich významných představitelů (sám autor knihy „Masky a zrcadla“) Anselm Strauss vydal rozsáhlý výběr z Meadova díla pod názvem „On Social Psychology“ (1966). O rozsáhlém vlivu Meadova díla na sociologii svědčí i „vypůjčky“ od Meada u strukturního funkcionalismu a zvláště u T. Parsonse.

Bylo již řečeno, že Mead na rozdíl od Thomase se nepodílel na žádném díle, které by znamenalo aplikaci jeho výchozích obecně teoretických a obecně metodologických tezí na empirický materiál. Jeho studie a přednášky mají ráz určitých pojmových a teoretických analýz, které vycházejí z určité obecné metodologie, která je zaměřena proti behavioristickému naturalistickému redukcionismu $\mathrm{v}$ interpretaci myšlení a já. $Z$ pozitivního hlediska jde o metodologii, která se podobá použití subjekt-objektové analýzy při výkladu vzniku myšlení a já ze sociální interakce a komunikace. Navíc Mead pod vlivem Wundta věnuje velkou pozornost problematice gest a jazyka a zdůrazñuje výrazně symbolický ráz lidské komunikace a interakce. Určité nesporné vlivy 
při analýze významů, znaků a symbolů procesů interakce jsou čerpány z vlastní americké pragmatické filozofie (Pierce, James). Zájmem o problematiku znaků a symbolů mohl Mead částí svého díla i akcentem své metodologie ovlivnit i představitele sémiotiky a teorie znaků (Ch. W. Morrise).

Metoda subjekt-objektové analýzy je zcela nesporně př́stupem, který má vždy obecně a u Meada konkrétně v sobě prvky dialektiky. Mead ze všech významných amerických pragmatistů, nebo těch, kdo částečně z pragmatismu vycházeli, má ve své metodologii i ve svých analýzách na této metodologii založených nejvíce prvků dialektické metody a dialektického myšlení. Vliv německé filozofie na pragmatismus je všeobecně uznáván. Může to být samozřejmě vliv selektivní, v určité míře a proporci, kdy se více jedním autorem spíše přejímá idealismus než dialektika, navíc i dialektika německé klasické filozofie je idealistická a může být tedy určitým způsobem u určitého autora mystifikována (podle známého Marxova výrazu). Vlivy německé idealistické filozofie a dokonce i Hegelovy filozofie na Meada jsou zřejmé a jsou i doloženy.

$\mathrm{Na}$ bázi svých základních metodologických východisek - zaměření proti natural istickému behaviorismu, zdůraznění sociální podmíněnosti myšlení a já jako produktu interakce a komunikace, subjekt-objektové analýzy Mead rozpracoval řadu podnětných výchozích koncepcí, které později formovaly rozvíjení symbolického interakcionismu, nebo byly prrijímány i strukturním funkcionalismem. Jde o jeho teorii interakce, analýzu gest a jazyka. Dále je to jeho teorie o vzniku sociálního já, spjatá se základními pojmy dosti originální teorie sociální role. Také $\mathrm{v}$ teorii sociální role, která současně přechází v relativně ucelenou koncepci socializace individua ve společnosti, Mead vychází z pojmu postoj, který je základem interpretace sociální role. Roli nechápe Mead jako souhrn očekávaného chování, které se váže na nositele určité sociální pozice, ale jako přejímání a hraní postojů, jimiž jedinec přejímá své společenské vlastnosti a znaky. Další součástí jeho teorie sociální role je teorie spontánní hry a organizované hry - termíny play a game, které jsou způsobem, jak se socializované individuum učí hrát společnost a vytváří sebe jako sociální bytost. Sociální determinace procesu socializace je u Meada vyjádřena v terminologii významných druhých (rodina a blízcí - tedy $\mathrm{v}$ podstatě primární skupiny) a zobecněných druhých - obecné a neosobní požadavky širší společnosti, než jsou jen primární skupiny.

Nesporná dialektika je obsažena v Meadově koncepci vrstev nebo složek sociálního já (Self), když rozlišuje složku „Me“ jako tu část nebo vrstvu socializovaného já, která je odpovědí na požadavky a postoje společnosti, jež jsou internalizovány zvenčí a na část nebo složku I, která je aktivní formou a způsobem reakce individua na společenské nároky. Sociální já (Self) je tedy něco, co vzniká v procesu, v dění, jsou to různé fáze samotného Self. Postoje, které člo- 
věk od společnosti převzal, jsou přítomny v jeho vlastní zkušenosti, ale jeho odpověd' na ně bude obsahovat aktivní vědomé a dokonce i nové prvky. Me je společenské, konvenční, zvykové, I je osobní, aktivní, tvořivé, iniciativní a autonomní. Podobné dialektické prvky má i Meadova koncepce mnohonásobného já, která vychází z množství situací, interakcí a tudíž i vztahů, do nichž vstupuje, jichž se zúčastní a v nichž jedná individuum. Sama individuální totožnost je proměnlivá. Podle Meada existují různé druhy já odpovídající všem druhům různých sociálních vztahů. Mead tak nadhodil otázku o nejistotě, proměnlivosti a labilitě sociálního já ve společenských poměrech, jejichž podobu a historickou podmíněnost již bohužel nezkoumal.

Zde jsme se také přiblížili ke slabinám jeho metodologického př́ístupu, které se pak odrážejí i v teoretických koncepcích. Mead prá vem zkoumá vznik myšlení i já v sociálním kontextu, poukazuje právem na význam gest, jazyka a symbolů v procesu lidské interakce a komunikace. Rozvinul atraktivní a vlivnou koncepci sociální role, přejímání postojů, podnětně poukázal na význam živelné i organizované hry pro proces socializace individua, rozčlenil vlivy společnosti na socializační proces $v$ kategoriích významných a zobecněných druhých. Poukázal rovněž oprávněně na dialektiku vztahu složek já (Self) jako na dialektiku I a Me. Zdůraznil zcela v duchu německé idealistické ale i dialektické filozofie aktivitu, tvořivost, iniciativu a autonomnost subjektu. $\mathrm{V}$ koncepci mnohonásobného já naznačil dialektickou problematiku množství organizovaných postojů a vědomých odpovědí na ně $v$ procesu bohatých, mnohostranných společenských vztahů.

Proto sovětský kritik Meadovy koncepce L. G. Jonin zdůrazňuje, že patos meadovské sociální psychologie je úplně jasný a relativní pokrokovost jeho idejí je pro jeho dobu nesporná" ${ }^{6}{ }^{6}$ ) Zde by bylo třeba dodat, že toto hodnocení potřebuje upřesnění. Meadovy koncepce jsou rélativně pokrokové a inspirativní i dnes, zejména $\mathrm{v}$ kontextu americké společnosti. Jeho koncepce jsou ve vztahu $\mathrm{k}$ názorům zjednodušeného behaviorismu, empirismu, naturalistického psychologismu i dnes relativně pokrokové v kontextu americké buržoazní sociologie a sociální psychologie. Mohou být pro jednotlivé autory zprostředkujícím článkem přechodu $\mathrm{k}$ dialektičtější a hlubší koncepci vztahu individua a společnosti. Mohou být protikoncepcí proti strukturně funkcionalistické, deterministické a zjednodušující koncepci sociální role, jako souhrnu institucionalizovaných požadavků na chování jednotlivce $\mathrm{v}$ duchu totálního konformismu a úplného pohlcení individua společností.

$\mathrm{Z}$ hlediska marxisticko-leninského hodnocení je však nutno zcela jedno-

$\left.{ }^{6}\right)$ L. G. Jonin: Kritika sociaĺnoj psichologii Džordža Mida i jejo sovremennych interpretacij. Sociologičeskije issledovanija, 1975,1 , s. 175 . 
značně poukázat na určité zásadní nedostatky $\mathrm{v}$ metodologii i $\mathrm{v}$ teoretických tezích G. H. Meada. Jeho prvky dialektického př́ístupu ke vztahu individuum společnost mají rysy dialektiky abstraktní s četnými rysy dialektiky idealistické. Jonin vytýká Meadovi převládající sociální psychologismus a nedostatek konkrétní sociologické analýzy. Poukazuje na jeho ahistorismus a netrrídní př́stup. Společnost vyjadřovaná $\mathbf{v}$ Meadových pojmech významní druzí a zobecnění druzí je interpretována nekonkrétně, zásadně u Meada chybí sociálně třínní přístup. Také jeho analýza postojů, symbolů a významů je analýzou, $v$ níž zcela zjednoznačně chybí jakákoliv zmínka o třídním rozdělení společnosti, o tom, že postoje a hodnoty, symboly a významy jsou poznamenány třídním antagonismem. Proto také mají Meadovy přistupy $\mathrm{k}$ závažným otázkám vztahu individua a společnosti značně formalistický ráz. Právě tyto vnitřní nedostatky Meadových metodologických a teoretických východisek byly základem jeho možné různorodé interpretace včetně možné tendence $\mathrm{k}$ subjektivně idealistickému pojetí jeho hlavních, byt' i podnětných a zárodečně dialektických postřehů a objevů. Tendence $\mathrm{k}$ subjektivně idealistickému pojetí Meadovy metodologie i jeho teoretických přínosů se skutečně, jak ukážeme později, staly východiskem některých soudobých představitelů symbolického interakcionis$\mathrm{mu}$, kteří sami byli zprostředkujícím článkem $\mathrm{k}$ vytváření fenomenologické sociologie šedesátých let $\mathrm{v}$ USA.

Výtky proti Meadovi za jeho abstraktní, formalistický, nehistorický a málo sociologický přístup s nedostatkem pochopení pro třídní charakteristiku americké společnosti (vždyt' Mead mluví spíše o společnosti vůbec) lze téměř ve stejné míře uplatnit i na základní koncepce W. I. Thomase. I jeho pojetí postojů, dialektiky a vzájemného působení individua (osobnosti) a společnosti, jeho pojetí situace a definice situace je mimo dobu a čas konkrétní historické, tj. především americké třídní společnosti.

Tyto základní a důležité kritické výhrady proti Meadovi a Thomasovi jako dvěma nejdůležitějším představitelům zakladatelské generace symbolického interakcionismu, který ve svérázné kombinaci spojuje dílčí prŕnosy pragmatismu a německé idealistické filozofie však nemají a neměly být důvodem pro podcenění jejich dílčích pozitivních přínosů a postřehů, které jsou nesporně jedním z důvodů jejich značného pozdějšího vlivu na americkou sociální psychologii a sociologii po druhé světové válce.

Ke zvláštnostem vývoje buržoazních společenskovědních disciplín patří i ta skutečnost, že se vyvíjejí jako střetávání a spory mezi mnoha různými směry a školami, z nichž každá představuje často silnou kritiku jednostranností a slabých stránek jiného směru a sama je zase podrobena kritice ve svých slabostech a jednostrannostech jinými školami a směry. Buržoazní společenskovědní disciplíny se vyvíjejí také tak, že se $\mathrm{v}$ nich na rozdíl od marxismu-leninismu 
objevují a nastolují různé závažné problémy metodologické i teoretické opožděně nebo zkresleně a deformovaně. Pro pochopení vývoje buržoazní sociologie a sociální psychologie to však má svůj význam. Tam, kde není velká nebo žádná tradice materialistické filozofie a z ní vycházející sociologie jako právě v USA, tam, kde není silný nebo dostatečný vliv marxisticko-leninské teorie, může idealistické filozofie představovat relativní pokrok $\mathrm{v}$ kontextu konkrétního historického vývoje buržoazních společenskovědních disciplín. V tomto smyslu jsou některé metodologické a $\mathrm{z}$ nich vycházející teoretické i badatelské výsledky Thomase a Meada pozitivní a zaslouží si nejen kritické, ale i objektivní zhodnocení pro své dílčí př́ínosy.

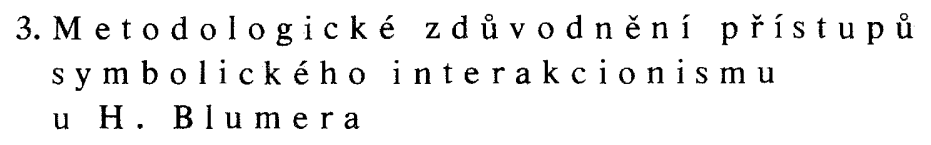

Herbert Blumer patří k nejvýznamnějším systematikům a teoretikům směru, jehož zakladateli byli W. I. Thomas a G. H. Mead, i když původně název symbolický interakcionismus pro tuto školu nebyl používán a Thomas i G. H. Mead byli zařazování pod používanější termín sociální behaviorismus. Vlastní termín výslovně pochází od $\mathrm{H}$. Blumera, který ho považuje za výstižný, byt' i poněkud barbarský. Blumer sám vystudoval na Chicagské univerzitě a byl doslova žákem G. H. Meada. Od roku 1927 do roku 1952 prrímo působil na oddělení sociologie Chicagské univerzity jako učitel. V podstatě po smrti Meadově v roce 1931 ho nahradil jako intelektuální vůdce a dokonce i organizátor směru symbolického interakcionismu. Postupně se stal ve svých statích a nakonec i ve své syntetizující práci z roku 1969 jakýmsi oficiálním vykladačem základních metodologických, pojmových a tẹoretických východisek symbolického interakcionismu s velkým důrazem na zdůvodnění specifických metod tohoto směru.

První programový článek Blumera pochází ještě z roku 1938. Není však u nás dostupný. Má název „Sociální psychologie“. Zajímavá je také ta skutečnost, že Blumer byl paralelně se vzestupem strukturního funkcionalismu zásadním odpůrcem všech základních metodologických a teoretických východisek tohoto směru. Zvláště po druhé světové válce vychází několik jeho koncepčních statí. Jde o statě „What is wrong social theory?“, ASR 19, February 1954, "Sociological analysis and the „Variable“, ASR 21, December 1956, „The sociological implications of the thought of George Herbert Mead", AJS 71, March 1966, Symbolic Interactionism: Perspective and Method, New Jersey 1969. Základní výtah výchozích metodologických a kategoriálních určení symbolického interakcionismu byl také zařazen $\mathrm{v}$ německém překladu $\mathrm{v}$ knize 
Arbeitsgruppe Bielefelder Soziologen (Hrsg.) Alltagwissen, Interaktion und gesellschaftliche Wirklichkeit 1, Reinbek bei Hamburg 1973, str. 80-146.

Ve své shrnující práci Blumer uvádí základní principy symbolického interakcionismu a pak zvláště zevrubně vykládá specifické a podle něho efektivnější metody sociologického zkoumání, než jsou standardní metody empirické výzkumné sociologie nebo strukturního funkcionalismu.

Podle Blumera spočívá symbolický interakcionismus na 3 základních principech: 1 . Lidé ve vztahu $\mathrm{k}$ věcem jednají na základě významů, které pro ně věci mají. Ovšem ve vztahu ke kategorii věci je třeba vědět, že Blumer za ně považuje vše, co člověk může ve svém světě vnímat - jsou to fyzické předměty, druzí lidé, ale též instituce, ideály, jimiž se lidé řídí, jednání druhých osob a vůbec situace, $s$ nimiž se lidé setkávají v denním životě. 2 . Význam takových věcí může být odvozen nebo vzniká ze sociální interakce, do níž člověk vstupuje se svými bližními. 3. Tyto významy jsou lidmi užívány a měněny $v$ interpretativním procesu, který lidé používají při setkání s věcmi. Jde tedy o tři základní termíny - význam, interakce a interpretace. $K$ těmto třem pojmům přiřazuje Blumer další meadovské kategorie jako gesta, převzetí role druhého (role jako přejímání postojů), označení a jednu z hlavních kategorií $\mathrm{H}$. G. Meada Self.

Pro účely naší analýzy je však nutno se především zaměřit na Blumerův výklad základních a nejdůležitějších metodologických postupů, které Blumer považuje především za specifické pro symbolický interakcionismus. Metodologická východiska však Blumer vyvozuje z předpokládaného charakteru sociální reality. Nesouhlasí s tím, že většina sociologických př́ruček je založena na přesvědčení, že lidská společnost existuje ve formě pevného životního pořádku a tento pořádek spočívá $\mathrm{v}$ dodržování řady pravidel, norem, hodnot a sankcí, které lidem přesně předepisují, jak mají v různých situacích jednat. Proti tomu Blumer namítá, že není pravda, že by plná šíře života v nějaké společnosti byla jen výrazem předem hotových forem společenského jednání (z kontextu je zřejmé, že Blumer kritizuje koncepci strukturního funkcionalismu o společnosti jako řádu). $V$ rámci lidského soužití vznikají podle Blumera stále nové sitauce, které jsou problematické a pro něž se jeví existující pravidla jako nedostatečná. Podle Blumera jsou sféry nepředepsaného chování v lidském soužití velmi časté.

Ale i případy předepsaného a opakovaného chování se musí počínat znovu. I zde musí účastníci budovat nové linie svého jednání dvojitým procesem pojmenování a interpretace. Společnost je podle Blumera souhrnem osob, které žijí ve společnosti $\mathrm{v}$ neustálém procesu interakce. Tento interakční proces spočíá v tom, že účastníci interakce oznamují druhým, co mají dělat tím, že sami interpretují oznámení druhých. Žijí ve světě objektů, s nimiž spojují význa$m y$. Zde Blumer př́mo vychází z určitých filozofických východisek, když poukazuje na to, že svět skutečnosti existuje jen v lidské zkušenosti a že je zřejmý 
jen v té formě, jak lidé tento svět „vidí“. Samozřejmě, že empirický svět je také reálný v duchu realistů (zde myslí Blumer v podstatě stanovisko materialistické. E. U.). Ale neexistuje v konečné a neměnné formě. Přitom nemůžeme skutečnost empirického světě chápat ve formě výsledků přírodních věd.

Vše, co bylo shora uvedeno, má velký význam pro metodologii symbolického interakcionismu. Metodologie se podle Blumera vztahuje k celkovému procesu zkoumání specifického charakteru da ného empirického světa. Metodologie proto zahrnuje celkové vědecké bádání a nejen vybranou část nebo aspekt onoho bádání. Každá část vědeckého bádání musí odpovídat stejně jako celkové vědecké jednání specifickému charakteru zkoumaného empirického světa. Proto jsou metody podřízeny empirickému světu a měly by být také podrobeny zkoumání a prověření v tomto světě. Proto také je to empirický svět, který má být základem pro odpověd' o rázu používaných metod a ne nějaký model vědeckého zkoumání světa. Celkovým smyslem těchto úvah je tedy tvrzení, že metoda zkoumání reality nemá být nezávislá a konstruována mimo reálný svět, naopak má vycházet $\mathrm{z}$ tohoto světa a má mu být ve své prověrce podrobena.

Blumer je proti ztotožňování metodologie jen s částí (a to omezenou) vědeckého jednání, například proti ztotožnění metody vědeckého poznání s moderními kvantitativními postupy. Metodolog není pro něj někdo, kdo je vynikajícím způsobem zběhlý ve znalosti a použití takových metod a postupů. Blumer $\mathrm{v}$ podstatě kritizuje nezávislost metodologie na specifickém charakteru empirického světa. Jak tedy podle Blumera máme zkoumat empirický svět, který je pro něj světem každodenním (zde se objevuje též další termín, který původně u Meada ani Thomase není, je to termín každodenní svět). Empirický sociální svět je svět každodenní zkušenosti, je to vrchní vrstva toho, co v našem životě vidíme a v životě druhých poznáváme. Velmi ostře se Blumer obrací proti těm vědcům, kteří neznají obvykle ani trochu empirický sociální svět a přesto se odvažují k němu vědecky přistoupit jenom proto, že jsou přesvědčeni, že předem hotové obrazy a stereotypy o světě, které převzali z oboru, jim dávají právo a možnost poznat empirický reálný svět, který vůbec předtím neznali a neznají.

Aby bylo možno poznat svět, který chce sociolog zkoumat, nestačí, aby sebevědomě používal těch metod a postupů, které mu jeho věda dává jako naprosto spolehlivé. Proto Blumer navrhuje specifickou metodu, kterou nazval explorace. Této metodě a termínu, jimž ji vyjadřuje, připisuje specifické vlastnosti. Jde o metodu, která má umožnit, aby bylo dosaženo navzájem se doplňujících a spojených cílů. 1 . Umožnit badateli, aby se důvěrně a všestranně seznámil s oblastí sociálního života, kterou zkoumá, již však ale ve většině případů nijak předem nezná a není s ní nikterak obeznámen. 2 . Nastínit a zlepšit jeho výzkum tak, aby jeho problémy, jeho výzkumné zaměření, jeho data a analytické vztahy 
i interpretace vyplývaly ze zkoumaného empirického světa, v němž jsou a mohou být především zdůvodněny. Explorace je pružný postup, v němž badatel stř́idá jednu výzkumnou metodu za druhou, zaujímá v průběhu svého studia reality nové pozice pozorování, $v$ němž se pohybuje v novém směru, o kterém dříve néuvažoval. $V$ tom to postupu mění své mínění o tom, co jsou důležitá data, když získal více informací a lepší pochopení té reality, kterou zkoumá. Explorativní výzkum klade Blumer proti předepsanému a omezenému způsobu, který je dnes vyžadován od současného pojetí vědecké práce. Flexibilitu explorativního zkoumání nelze však chápat tak, že by vůbec nedávala žádné zaměření výzkumu.

Spíše jde o zdůraznění toho, že na začátku bývá výkumný cíl stanoven př́liš široce, a proto se musí v průběhu zkoumání postupně zužovat a konkretizovat. Cílem explorativního výzkumu je dospět $\mathrm{k}$ jasnému pochopení toho, jak se má klást problém, dále zjistit, která data jsou přiměřená pro daný problém, rozvinout představy o významných spojovacích liniích a navrhnout konceptuální prostředky, se zřetelem na to, co se badatel dozví o té sféře života, kterou zkoumá. Toto pojetí a tento přístup se podle Blumera liší významně od povýšené pozice badatele, od něhož se v běžném existujícím vědeckém programu vyžaduje, aby poskytl od začátku studia pevný a jasně strukturovaný problém a předpokládá se, že ví přesně, které druhy dat má sbírat a že má po ruce svůj připravený soubor technik a že uspořádává své výsledky pomocí předem stanovených kategorií. Explorativní zkoumání není vázáno předem na nějaký určitý soubor technik - má a může používat každý způsob postupu, který zaručuje určitou pravděpodobnost, že bude získán přesnější obraz o tom, co probíhá ve sférée sociálního života, jež je předmětem zkoumání. Explorativní metoda může zahrnovat přímé pozorování, rozhovor, získání životopisu, zvukové snímky komunikace zkoumaných osob, použití dopisů a deníků, provedení skupinových diskusí. Nebo je dobré vyhledat účastníky interakce, kteří jsou výborní pozorovatelé a dobře informováni, z nich je možné vytvořit diskusní a informativní skupinu, což je podle Blumera daleko efektivnější a užitečnější než reprezentativní náhodný výběr. Přitom musí být výzkumník stále připraven přezkoumat a měnit své představy, názory, koncepce o oblasti života, kterou zkoumá. Cílem explorativní metody je rozvinout a realizovat, naplnit ve shodě s okolnostmi co možná nejrozsáhlejší a nejpřesnější obraz zkoumané oblasti, a to umožňuje výzkumníkovi být doma ve zkoumané oblasti, to mu dává jistotu, že o zkoumané skutečnosti skutečně něco podstatného ví.

Vedle explorace navrhuje Blumer ještě další postup, který nazývá anglickým výrazem inspection (volně to může znamenat kontrolu, prověrku). Také v tomto smyslu interpretuje tento termín i Blumer. Je to intenzívní a koncetrované prověřování empirického obsahu všech libovolných analytických prvků, jakož 
i tomu odpovídající prověrka empirických vlastností vztahů mezi takovými prvky. Analytické prvky jsou všechny možné obecné nebo kategoriální jednotlivé prvky, které jsou v analýze použity, jako např. integrace, sociální mobilita, asimilace, charismatické vůdcovství, byrokratický vztah, systém autority, morálka, relativní deprivace, postoje atd.

Inspekce sestává z prověrky daných analytických prviků způsobem, který Blumer srovnává s postupem, jak zacházíme $s$ předmětem, který neznáme. Prototyp inspekce představu je naše zacházení s cizím fyzikálním předmětem: zvedáme ho, pozorujeme ho, otáćíme ho během pozorování, díváme se na něj $\mathrm{z}$ toho či onoho úhlu, klademe si otázku, co by to mohlo být, pak se vracíme, obracíme opět předmět zpět do původní polohy a konfrontujeme se s ním vzhledem $\mathrm{k}$ našim otázkám, zkoušíme ho a prověřujeme tím či oním způsobem. Toto přesné a měnící se zkoumání je podstatné na inspekci. Taková inspekce totiž není předem hotova, rutinizována nebo předepsána, stává se něčím takovým jen poté, když již víme, oč jde, a proto můžeme například použít testu. Inspekce je podle Blumera spíše flexifibilní, plná fantazie, je tvořivá a svobodná, razí nové směry. Inspekce je v Blumerově pojetí opakem postupu operacionalizace. Ten, kdo používá inspekce, se snaží určit vlastnosti analytických elementů intenzívním výzkumem jejich daností v empirickém světě. Protože se použití inspekce opomíjí, je použití analytických elementů $v$ současném sociálněvědním výzkumu určitým způsobem, jak říká Blumer, skandální. Nikde to není prý zjevnější než na stavu běžných koncepcí, které vykládají analytické prvky. Převážná většina našich koncepcí je podezřele vágní a nepřesná ve svém empirickém obsahu, a přesto je používáme stále ve svých analýzách bez omezení, bez snahy a rozpracování, vyjasnění a prověření jejich empirického obsahu. Žádoucí zlepšení jejich empirického významu se nedosáhne nikterak „operacionalizací pojmů“. Toto můžeme dosáhnout jedině pečlivou inspekcí jejich empirických daností, v jejím průběhu se izoluje a vysvětluje specifikum empirických daností.

Explorace a inspekce tak tvoří nutné způsoby postupu pro přímou prověrku empirického sociálního světa. Zahrnují to, co se někdy nazývá „naturalistický výzkum", který je zaměřen na daný empirický svẹt v jeho přirozené, probíhající specifice a ne na simulování takového světa, nebo na jeho abstrakci (jak se to děje v případě laboratorního experimentu), nebo na nahrážku tohoto světa ve formě nějaké předem hotové představy. Zásluha naturalistického studia je v tom, že bere v úvahu empirickou oblast a zůstává jí blízko. Zde ovšem nemá Blumer na mysli kopírování metod přírodních věd, naturalistický výzkum vysvětluje na př́kladu Darwina. Ten prý rovněž byl v prímém kontaktu s empirickou př́rodou, $\mathrm{z}$ ní vyvodil své postupy a pak také vědecky interpretoval. $\mathrm{Z}$ metodologického hlediska je symbolický interakcionismus na skutečnost 
vázaný přístup $\mathrm{k}$ vědeckému zkoumání lidského soužití a lidského chování. Jeho empirický svět je přirozený svět takového soužití a chování. Zakotvuje své problémy $\mathrm{v}$ tomto přirozeném světě, vede své výzkumy $\mathrm{v}$ něm a odvozuje své interpretace $\mathrm{z}$ takového naturalistického zkoumání - jde tedy o př́mé prověřování empirického sociálního světa. Symbolický interakcionismus není chybně veden mýtickou vírou, že kvůli vědeckosti je nutné utvářet zkoumání tak, že odpovídá předem hotovému programu empirického zkoumání tím, že například přejímá pracovní způsob moderních př́rodních věd, nebo předem navrhuje pevný logický nebo matematický model, nebo vnucuje studium reality ve statistickém či matematickém rámci, nebo ho provádí podle předem hotových proměnných, nebo že ho omezuje na zvláštní standardizovaný postup ve formě dotazníku.

Po výkladu základních dvou metodických postupů explorace a inspekce pak Blumer shrnuje podstatu symbolického interakcionismu znovu takto: Lidé jsou individuálně nebo kolektivně zaměřeni na jednání na základě významů objektů, které tvoři jejich svět. Spojení lidí se děje nutně ve formě procesu, $v$ jehož průběhu si navzájem něco oznamují, ohlašují a tato oznámení či pojmenování druhých lidí také interpretují. Sociální jednání je vybudováno a vytvářeno v procesu, v němž jednající interpretují a oceňují situace, s nimiž se setkávají. Jsou to komplexní řetězy jednání, které tvoří organizace, instituce, dělba práce a sítě vzájemných závislostí, jsou to dynamické a ne statické záležitosti.

Zdůraznění podstatné role významụ a interpretací, jimiž účastníci interakce vykládají a v nichž vidí své jednání, je předpokladem dalšího metodologického principu symbolického interakcionismu. Vědec musí vidět realitu tak, jak ji vidí, pojmenovávají a interpretují sami účastníci, vědec se musí oprostit od profesionálního předsudku, že účastníci interakce vidí a označují svět jako on. Jeho interpretace a závěry musí vycházet $\mathrm{z}$ interpretací a významů vlastních účastníků interakce a tomu musí být podrobeny všechny základní metodologické přístupy. Apriorní metodologické př́ístupy $\mathrm{k}$ jakékoli oblasti reality chápané jako závazné, nutné a předem vědecké, zabraňují př́mému proniknutí $\mathrm{k}$ realitě a v podstatě tuto realitu zkreslují a deformují. Jednoduše řečeno, zkoumající musí vidět a zkoumat realitu tak, jak ji vidí a interpretují sami účastníci a tomu musí podrobit, př́padně na základě toho obměnit, upřesnit a zdokonalovat své metodické postupy.

Blumer tedy v podstatě jako systematik názorů G. H. Meada a W. Thomase shrnul a také ve své vlastní interpretaci vyložil základní metodologické přístupy a zásady symbolického interakcionismu. Je to především jeho pojetí metody explorace a inspekce kombinované se základními koncepcemi interakce, významů a interpretace. $\mathrm{V}$ jeho pojetí je symbolický interakcionismus směrem, který metody zkoumání sociální reality podrobuje povaze reality samé i význa- 
mům a interpretacím laických účastníků sociální interakce. Blumer je ostrým kritikem všech metodických koncepcí empirismu, behaviorismu a pozitivismu, ale i strukturního funkcionalismu. Jeho výtky proti standardním výzkumným metodám a praktikám nelze nechat bez povšimnutí a ignorovat ve jménu sebevědomého empirismu a pozitivismu s jeho přesvědčením o apriorní exaktnosti metod, jež používá. Blumer zproblematizoval, a to podle mého názoru právem, suverénní představu, že empirický sociolog může na základě standardizované, rutinní a schematické metodologie přistoupit ke zkoumání jakékoli reality a že jeho zpracování a výklad reality prostřednictvím standardních a osvědčených či samozřejmě používaných metod je automaticky vědecký. Blumer má i část pravdy tam, kde zdůrazňuje $v$ návaznosti zejména na Thomase oprávněné místo biografického př́stupu a metody zkoumání osobních dokumentů při studiu sociální reality. Ignorovat subjektivně významovou a interpretační stránku sociální interakce nelze ve jménu falešného boje proti subjektivismu a ve jménu stejně fetišistické a naturalistické koncepce objektivity.

Nedostatky Blumera jsou jinde. Lze mu právem vytknout, že zůstal pouze na úrovni vyhlášení svých specifických metodologických postulátů a že neprovedl sám jejich ověření a použití při svých konkrétních výzkumech, aby i výsledky výzkumu dokázal větší užitečnost či plodnost svých metodologických a interpretačních principů. Blumer zachovává i nedostatky, kritizované jako nedostatky Thomasových a Meadových koncepcí. Jeho podnětné kritické metodologické koncepce jsou i nadále zatíženy netřídním, abstraktním, nehistorickým a spíše formálně obecně vyhlašovaným přśstupem. V konfrontaci s těmito základními nedostatky je i oslabena zásada, že metody výzkumu mají odpovídat povaze empirické reality. Povaha empirické reality jako obsažného zdroje metodologických a logických forem konkretizována není. Navíc Blumer má tendenci přes naprosto oprávněné kritiky nároků empirismu a pozitivismu na metodologicko-vědecký monopol ignorovat sociálně historické i třídní podmínky vzniku a rozvoje empirické sociologie v USA; jeho kritika je především omezena na rámec metodologie, obecných pojmů a kategorií, sociální souvislosti metodologické koncepce mu unikají.

Vedle Blumera se po druhé světové válce jako představitelé symbolického interakcionismu dostávají do popředí i jiní američtí autoři; je to zejména Anselm Strauss, N. Glazer, M. Natanson, T. Shibutani, z mladších například $\mathrm{N}$. Denzin. Interpretace symbolického inaterakcionismu $\mathrm{v}$ díle Manforda Kuhna je spíše odklonem od klasického pojetí zakladatelů i Blumerovy koncepce. Blumerův významný žák $\mathrm{z}$ období jeho kalifornského působení po odchodu z Chicaga E. Goffman se v podstatě osamostatnil a stal se sám zakladatelem určitého specifického směru, který dostal název sociální dramaturgie. Návaznost je zejména na jednu s výżnamných kategorií symbolického interakcionis- 
mu, kategorii sociální role. Metodologie E. Goffmana je tak již přece jenom odlišná, i když by si zasloužila pro svủj vliv v USA i v NSR samostaný rozbor. ${ }^{7}$ )

Symbolický interakcionismus $\mathrm{v}$ zakladatelské koncepci G. H. Meada a W. Thomase, systematizovaný $\mathrm{H}$. Blumerem a dalšími stoupenci tohoto směru měl však ve vývoji americké sociologie a sociální psychologie ještě další specifickou, zprostředkující funkci. Stal se článkem spojujícím americkou sociologii a sociální psychologii se vznikající a stále vlivnější americkou fenomenologickou sociologií. Je možné dokonce říci, že existence směru symbolického interakcionismu v USA byla vůbec jednou z podstatných podmínek rozvoje a rozmachu fenomenologické sociologie $v$ USA.

\section{METODOLOGICKÉ PRINCIPY FENOMENOLOGICKÉ SOCIOLOGIE}

Fenomenologická sociologie má jednoznačně jeden určitý a přesně zjistitelný zdroj, je jím Husserlova filozofická fenomenologie. Jaké však byly složité a doslova klikaté cesty Husserlovy fenomenologické filozofie, jimiž se dostala $\mathrm{z}$ Německa až do USA? Jsou známy $\mathrm{v}$ rámci Německa tendence o přenesení filozofických podnětů Husserlovy fenomenologie do sociologie především z díla M. Schelera a potom i A. Vierkandta. Ty však samy o sobě neměly nějaký rozsáhlý vliv na vývoj německé sociologie mezi dvěma světovými válkami a rozhodně pak už ne v USA. Ve Spojených státech byli již před druhou světovou válkou jednotliví nepočetní stoupenci Husserlovy fenomenologické filozofie. Byl to např́íklad M. Farber. Ti však neměli žádný významný vliv na rozvoj americké sociologie. Úkol přenést podněty husserlovské filozofie do USA a tam zejména pak do sféry sociálních věd a zvláště sociologie připadl filozofovi rakouského původu A. Schützovi. O jeho zprostředkovatelské a doslova vůdčí roli pro rozvoj americké fenomenologické sociologie jsem pojednal na jiném místě. $\left.{ }^{8}\right)$ Zde však vzhledem k základnímu zaměrení této studie jde především o hlavní metodologické přístupy, jež jsou příznačné pro americkou fenomenologickou sociologii. $\mathrm{V}$ této souvislosti je alespoň částečně třeba řešit otázku, do jaké míry má v sobě Husserlova filozofie určité vyslovené nebo implicitní metodologické předpoklady, které by se mohly stát přímo nebo zprostředkovaně východiskem metodologie fenomenologické sociologie. Při hledání odpovědi na

${ }^{7}$ ) Viz kritickou interpretaci symbolického interakcionismu i sociální dramaturgie $\mathrm{v}$ sovětské kolektivní práci pod vedením L. G. Jonina a G. V. Osipova: Kritika sovremennoj buržoaznoj teoretičeskoj sociologii. Moskva 1977, s. 68-94.

$\left.{ }^{8}\right)$ Viz E. Urbánek: Fenomenologická sociologie - vlivný směr americké buržoazní sociologie. Sociologický časopis, 1981,1 , s. 35-50. 
tuto otázku nám pomůže práce západoněmeckého sociologa $\mathrm{H}$. Braunera, který si výslovně klade úkol prozkoumat, do jaké míry obsahuje Husserlova fenomenologie teoretické ale i metodologické podněty pro sociologii. ${ }^{y}$ )

Brauner v podstatě velmi zevrubně zkoumá jednak vlastní Husserlovo dílo, jednak rozsáhlou husserlovskou literaturu německou i anglosaskou a některé jeho závěry lze použít. Navíc jde o práci z poslední doby, která zachycuje všechny základní výboje husserlovské filozofie ve vztahu $\mathrm{k}$ sociologii.

Brauner především uvádí základní námitky o významu nebo důležitosti Husserlovy filozofie pro sociální vědy vůbec a sociologii zvláště. Velmi rozšířené kritické hodnocení Husserlovy filozofie ve vztahu k sociálním vědám i filozofii před rozmachem fenomenologické sociologie shrnuje Brauner takto: 1. Husserlova filozofie zůstává stát u pouhé egologie a je pro sociální vědy irelevantní. 2. Husserlovo myšlení vede $\mathrm{k}$ idealistické transcendentální filozofii, která je pro moderní sociální vědecké teorie nezajímavá. 3. Orientace na filozofické ideje je pro sociální vědy beztak škodlivá a zabraňuje jejich emancipačnímu procesu $\mathrm{k}$ samostatným vědecko-empirickým disciplínám. 4. Použitá metoda fenomenologie - zření podstat - je čistá spekulace a není intersubjektivně prověřitelná, a proto je nutné ji odmítnout jako nevědeckou. ${ }^{10}$ ) Jako doplněk uvádí Brauner ještě dnes již poněkud kuriózní názor známého západoněmeckého sociologa Königa, že podle Königova chápání vědy není fenomenologie žádným přímým tématem sociologie. Skutečný stav a zvláště vliv fenomenologie ké sociologie v USA, v NSR, ale také i v Anglii dokazu je, že König byl v tomto ohledu špatným prorokem.

Je faktem, že fenomenologická metoda zření podstat nebo pojetí fenomenologické redukce jako metodologického postupu nebyla a není ani přímým zdrojem konstituování fenomenologické sociologie. Na druhé straně však zůstává faktem, že husserlovská fenomenologická filozofie sociologii ovlivnila a stala se některými svými částmi, zprostředkována především Schützem, nesporným základem formování fenomenologické sociologie. Brauner to formuluje tak, že říká toto: „Fenomenologie není ani uzavřená teorie, ani neposkytla metodu vyhovující kritériu intersubjektivní prověřitelnosti - spíše poskytla program, který by měl umožnit sociologii analýzu výkladu smyslu a procesů kladení smyslu, které realizují ti, kdo žijí v sociálním světě“. ${ }^{11}$ )

Avšak vlastní metodologické principy, které měly vliv na rozvoj fenomenologické principy, rozvinul v návaznosti na Husserlovy práce $\mathrm{z}$ jeho posledního období především A. Schütz.

$\left.{ }^{9}\right)$ H. Brauner: Die Phänomenologie Edmund Husserls und Bedeutung für soziologische Theorien. Meisenheim am Glan 1978.

$\left.{ }^{10}\right)$ Viz H. Brauner, uved. práce s. 89.

11) H. Brauner, cit. práce, s. 92. 
A. Schütz byl nesporně v určité míře a v určitém rozsahu žákem Husserlovým. Studoval však nejen filozofii, ale i ekonomii a právo. Nebyl také ortodoxním husserlovcem. Již jeho první a vlastně jediné velké knižní dílo, které napsal a vydal za svého života bylo kombinací husserlovského př́stupu s určitými významnými vlivy metodologických a teoretických koncepcí Maxe Webera. Jde o práci z roku 1932 „Der sinnhafte Aufbau der sozialen Welt“, v níž jsou zcela jasné proporce vlivu Husserlovy filozofie i Weberovy metodologie. I když je zde Max Weber kritizován za to, že svou správnou myšlenku o tom, že sociální jednání ve společnosti je vždy spjato se smyslem, který mu přisuzují nebo připisují jednající, nespojuje s otázkou po konstituování tohoto smyslu, zůstal po celý vědecký život Schütze trvalou metodologickou inspirací. Kritika M. Webera je nesporně podnícena Husserlovým pojetím konstituce smyslu, avšak metodologie ideálních typů a vědeckého uchopení a pochopení subjektivního smyslu lidského jednání byla a zůstala jedním z klíčových problémů celoživotního Schützova díla. Je to otázka, jak vědecky, objektivně, vědeckými metodami zachytit subjektivní smysl jednání. Nejde tedy u Schütze o nějakou introspektivní metodu, vcítění a podobně, což se někdy nesprávně připisuje i $\mathrm{M}$. Weberovi.

Přes všechny kritické výhrady, které ve své první velké práci adresuje Schütz Weberovi, podržel i v dalších etapách své teoretické činnosti významné metodologické a teoretické podněty od $\mathrm{M}$. Webera. Jde o myšlenku o nutnosti vědecké teorie jednání a o metodu konstrukce ideálních typů, nebo jak ji později také alternativně Schülz nazýval konstrukce „homunkulü“ nebo loutek. Tyto myšlenky Schütz rozvíjel a zdokonaloval již jako emigrant ve Spojených statech, kam se uchýlil na počátku druhé světové války. Zde v přednáškové činnosti, ve statích, studiích i referátech rozvíjel své základní metodologické a teoretické přistupy, jimiž podstatnou měrou přispěl ke konstituování americké fenomenologické sociologie.

Schütz jistě vychází z německé duchovědní tradice. Součástí této tradice je zdůraznění rozdílu mezi př́rodními a společenșkými vědami a též i rozdílu mezi jejich metodami. Schütz však neklade proti sobě prrírodní a společenské vědy jako absolutně protikladné. Upozorňuje na rozdílnost jejich postupu při zkoumání př́slušné sféry reality. Bez ohledu na možné kritické výtky vůči koncepcím duchovědným, je zapotřebí říci, že rozdíly mezi přírodními a společenskými vědami existují, a to proto, že přírodní a společenská skutečnost nejsou skutečně totožné. Ignorovat odlišnost přírodní a společenské reality znamená $\mathrm{v}$ podstatě rozvíjení naturalistické redukce sociálna na jednodušší př́rodní 
realitu, tím se stírá nebo úplně ignoruje kvalitativní specifikum společenské reality.

I marxismus zdůrazňuje, že přes všechny možné a nutné formy souvislosti a zprostředkování sociální reality s prrírodou je prrírodní realita skutečností danou, kdežto sociální realita, společnost je skutečností tvořenou sociálně a historicky lidmi. Na rozdíl od přírodních procesů, které jsou v podstatě živelné, jsou sociální procesy vždy činnostmi, které lidi realizují za účasti účelného vědomí, vědomí je vždy vklíněno do lidské společenské činnosti, je vždy účastno na tvoření sociální reality, vzpomeňme jen na Engelsovu formulaci, že lidé dělají dějiny vždy s vědomím, nikoli vždy však vědomě a uvědoměle. Proto je nutné uznat racionální jádro duchovědního přistupu, který do určité míry oprávněně postuluje rozdíl mezi přírodní a společenskou skutečností a iaké právem $\mathrm{z}$ toho vyvozuje myšlenku o nestejnosti nebo netotožnosti metod přírodních a společenských věd.

Schütz tuto problematiku řeši ve svých kategoriích a ve své interpretaci. Uznává, že všechny vědy mají v té či oné míře stejná nebo obdobná procedurální pravidla, vztahující se ke správné organizaci myšlení. My bychom řekli, že jsou jim společná určitá logická pravidla vědeckého poznání. Tak například Schütz považuje za samozřejmé, že každé vědecké poznání (at' je v rámci přírodní, nebo společenské vědy) musí odpovídat postulátu logické konzistence. Schütz ho chápe tak, že ve shodě s tímto postulátem je nutné, aby systém typických konstrukcí nastíněných vědcem byl ustanoven s nejvy̌̌ším stupněm jasnosti a zřetelnosti konceptuálního rámce a musí být plně slučitelný s principy formální logiky. Jejich přísně logický charakter odlišuje myšlenkové objekty vědy od myšlenkových objektů myšlení zdravého rozumu. Tento postulát logické konzistence je závazný pro přírodní i společenské vědy.

Rozdíl mezi přírodními a společenskými vědami tkví podle Schütze především v tom, že jejich konstrukce jsou konstrukcemi různého stupně. Teoretické konstrukce prírodních věd jsou konstrukcemi prvního stupně. Fakta a události probíhající v prŕírodě nejsou předběžně ani vybrána, ani předběžně interpretována, neodhalují vnitřní struktury relevance (struktury významu). Významy jako takové nejsou vlastní prrírodě. Fakta, údaje a události, s nimiž př́rodní vědec pracuje jsou právě fakta, události $v$ jeho observačním poli, ale toto pole nic „neznamenác pro molekuly, atomy a elektrony.

Naproti tomu fakta, události a data, jež jsou tu před sociálním vědcem, mají zcela odlišnou strukturu ve srovnání s fakty a údaji i událostmi, které zkoumá př́rodovědec. Předmětem zájmu sociální vědy jsou jednající aktéri, lidské bytosti angažované a zapojené ve všech druzích sociálních vztahů. Tito aktéri jsou podle Schützova originálního výrazu determinováni svou individuální biografickou situací, mají svou zásobu vědění po ruce, sledují cíle, mají své 
účely a plány i motivy, mají i jako účastníci každodenního „životního světa“ (výraz Husserlův) určité koncepce světa, v němž žijí i o sobě jako o bytostech žijících $\mathrm{v}$ tomto světě. $\mathrm{V}$ podstatě interpretují, dávají smysl a význam všemu, s čím se v každodenním životním světě setkávájí. Jejich jednání, jakož i jednání druhých aktérů má pro ně smysl. Všechny předběžné koncepce a interpretace každodenního životního světa jeho praktickými, laickými účastníky musí být vzaty $\mathrm{v}$ úvahu při vypracování organizovaného vědění o sociální realitě v její plné konkrétnosti, $\mathrm{tj}$. jako zakoušené sociálními aktéry $\mathrm{v}$ jejich denním životě. J de tedy u společenské vědy o konstrukce druhého stupně, protože jejich vytváření musí brát zřetel na interpretace, které mají sociální aktéři o sobě, o druhém, o svém světě.

S tím souvisí dva další, ale již specifické postuláty platné pro společenské vědy. Jde o postulát subjektivní interpretace a o postulát adekvátnosti. Postulát subjektivní interpretace vyžaduje, aby pro vysvětlení lidského jednání se vědec ptal, jaký model individuálního myšlení může být konstruován a jaké typické obsahy mu musí být připisovány, aby byla vysvětlena pozorovaná fakta jako výsledek aktivity takového myšlení v pochopitelné relaci. Shoda s postulátem subjektivní interpretace dává možnost referovat o všech druzích lidského jednání, o jejich výsledcích vzhledem k subjektivnímu smyslu takového jednání, nebo vzhledem $\mathrm{k}$ výsledku, které takové jednání má pro aktéra.

Dalším postulátem je postulát adekvátnosti. Každý termín ve vědeckém modelu lidského jednání musí být konstruován tak, aby lidské jednání realizované $\mathrm{v}$ životním světě individuálním aktérem způsobem, který je vyznačen typickou konstrukcí, bylo pochopitelné jak pro aktéra, tak i pro jeho bližní v termínech interpretace zdravého rozu mu každodenního života. Shoda s uvedeným postulátem zaručuje shodu konstrukcí sociálního světa ve vědě s konstrukcemi zdravého rozumu o zkušenosti se sociální realitou. ${ }^{12}$ )

Konstrukce druhého stupně, jež jsou produktem sociální vědy, jsou právě ony ideální typy, které Schütz nazývá také svými vlastními termíny bud' homunkuly, nebo loutkami. To jsou ideální konstrukce vytvářené sociálním vědcem podle jeho uvážení, ale také ve shodě s jeho vědeckým problémem. Model sociálního světa je vytvářen prostřednictvím homunkulů nebo loutek či ideálních typů. Konstrukce ideálního typu je podřizena požadavku, že musí existovat relace mezi tím, co je připisováno homunkulovi a aktuálním chováním př́slušného aktéra na scéně sociální reality. To znamená, že aktér se musí poznat v homunkulovi a vidět $\mathrm{v}$ něm idealizaci sebe sama. Konstruování ideálních homunkulů je idealizací těch typizací a sebetypizací, které skuteční aktéři praktikují v každodenním životě.

${ }^{12}$ ) Viz A. Schütz: Selected Papers I. The Hague 1962. s. 43-44. 
Podobně jako u M. Webera, je i u A. Schütze mezi ideálním typem smysluplného jednání a skutečným jednáním aktéra $\mathrm{v}$ konkrétní situaci řada vztahů. Ideální typy určitým způsobem zobecn̆ují jedinečné akty jedinečných situací aktérů. Představitel vědy nahrazuje objekty zdravého rozumu myšlenkovou konstrukcí ideálního typu. Podle Schütze a jeho specifické terminologie žije jednotlivec $\mathrm{v}$ každodenním světě tak, že je určen svou minulou zkušeností, je determinován svou individuální biografickou situací. Ale představitel sociální vědy konstruuje typické vzory průběhu jednání, odpovídající průběhu události a teprve pak koordinuje $\mathrm{k}$ těmto typickým vzorům průběhu jednání personální typ, model aktéra, jehož si představuje jako nadaného vědomím. Připisuje mu dále ve specifické ryze schützovské terminologii řadu typických motivů „aby“ a motivů „protože“. Konstruovaný homunkulus není ničím jiným než původcem svých typických funkcí. Proto také v souvislosti s konstrukcemi modelů druhého stupně může Schütz navazovat na jednoho z uvedených čelných představitelů symbolického interakcionismu - G. H. Meada a na jeho teorii sociální role.

Schütz také přejímá a používá jeden z klíčových pojmů Husserlovy filozofie - pojem životního světa (Lebenswelt), jehož zkoumání Husserl věnoval zásadní pozornost ve svých pozdějších a zvláště posledních pracích. Husserlova filozofie je nesporně idealistická, přes všechny pokusy povznést se nad protiklady materialismu a idealismu. Je to egologie, učení o aktivitě vědomí já a jeho konstitutivních úkonů včetně konstituování významu. Jako každá egologie měla i Husserlova filozofie zásadní problém s tím, jak přejít od aktivního vědomí já ke druhým já a $\mathrm{k}$ jejich sociálnímu životu. Tento problém Husserl nikdy důsledně nevyřešil, což mu vytýká i Schütz. Svými pojmy životní svět, svět každodenní a přirozený postoj v životním světě vytvořil určité předpoklady pro přechod fenomenologie $\mathrm{k}$ sociální problematice, což je zvláště patrné v poslední Husserlově práci „Krize evropských věd“. Schütz interpretoval pojmy životního světa, každodennosti a prrirozeného postoje metodologicky i teoreticky tak, že se mohly stát a také staly základními pojmy fenomenologické sociologie. Metodologický smysl těchto pojmů zcela jasně zaměřuje fenomenologickou sociologii na zkoumání „činné stránky“, což odpovídá tradici německé idealistické filozofie i husserlovské fenomenologii. Navíc se v pojmu životního světa a každodenního světa dostává do zorného pole husserlovské filozofie a zprostředkovaně přes Schütze i do americké fenomenologické sociologie problematika praktického' světa ovšem v idealistické interpretaci Husserlovy filozofie a v méně idealistické (jde o rozdíl stupně) interpretaci A. Schütze.

S tím souvisí i další klíčový pojem Husserlovy filozofie - pojem intersubjektivity, použitý ve vztahu $\mathrm{k}$ charakteristice sociálního světa. I tento pojem Schütz přejímá a modifikuje v podobě přijatelné pro sociologii a její výzkumy. 
Pojem intersubjektivity má svůj vlastní metodologický obsah. Nadhazuje a vytyčuje klíčový problém o podstatě a povaze sociální reality a také na ni svým způsobem odpovídá. Metodologicky je pojem intersubjektivity pro charakteristiku sociálního světa podnětný (v rámci americké buržoazní sociologie), protože jednak navazuje na tradici amerického pragmatismu a symbolického interakcionismu, jednak zdůrazňuje ty aspekty sociální reality, které ignoroval nebo deformoval empirismus, pozitivismus a strukturní funkcionalismus v americké sociologii. Jde o ztotožnění sociální reality s realitou přírodní, o naturalistický redukcionismus, o absolutní ztotožňování metod př́rodních věd s metodami sociálních věd a o nepochopení činné, subjektivní stránky společenské aktivity člověka. V pojmu intersubjektivity, v tvrzení, že životní svět, každodenní svět je svou povahou vždy intersubjektivní, souhrnem vztahů mezi vědomými subjekty a aktivitou konstitutivních úkonů, které se projevují v záměrné (intencionální) a významové a smysluplné stránce životního světa, zdůraznila fenomenologická sociologie nesporný fakt účasti vědomí na tvorbě sociální reality a zprostředkovanost sociální reality účelným a aktivním vědomím.

Americká sociologie se od šedesátých let, $\mathrm{v}$ době ústupu strukturního funkcionalismu i oslabení vědecké atraktivity omezené empirické sociologie stále více obrací díky zprostředkující roli Schütze i na základě přínosů symbolického interakcionismu $\mathrm{k}$ fenomenologické sociologii. Ta se stává v seđmdesátých letech jedním z hlavních (i když ne jediným) teoretických směrů americké buržoazní sociologie s četnými a významnými vlivy i na sociologii anglickou a v Západním Německu. Přejímá od husserlovké filozofie a od Schütze řadu uvedených metodologických, teoretických, pojmových a kategoriálních podnětů, které dále ve svých různých proudech specificky akcentuje, obměňuje nebo dokonce selektivně vykládá po svém.

$\mathrm{Z}$ dalších kategorií i metodických podnětů, kterými Schütz působil na formování fenomenologické sociologie, lze zaznamenat jeho akcent na biograficky determinovanou sociální situaci jednotlivce, což již ve shodě s tradicí důrazu symbolického interakcionismu na biografickou metodu a osobní dokumenty vytváři vlivný metodologický proud, který preferuje takzvaný biografický přístup i zkoumání osobních dokumentů při výzkumu. Navíc mohla americká sociologie navázat na tradici W. I. Thomase a F. Znanieckého i na metodologické syntézy H. Blumera.

Velký dưraz na zkoumání všech forem vědomí, které jsou součástí životního světa, světa každodennosti, všech významných interpretací a typizací, jimiž účastníci vykládají svou interakci vedl u Schützových stoupenců $\mathrm{k}$ novému pojetí sociologie vědění. Nejde jen o zkoumání systematických a usoustavněných forem vědomí typu ideologie nebo mýtu či utopie, jde o zkoumání každého a všech typů všedního vědomí, jehož prostrednictvím účastníci interakce 
interpretují svou interakci a dávají ji určitý význam a smysl. V této linii rozvíjeli fenomenologické interpretace schützovské sociologie vědění zvláště odchovanci Schütze P. Berger a T. Luckmann. ${ }^{13}$ )

Nejpočetnější směr nebo školu americké fenomenologické sociologie tvoří takzvaná etnometodologie reprezentovaná především A. Cicourelem a H. Garfinkelem. Jejich práce ze šedesátých a sedmdesátých let navazuje na Schütze, čerpají i z amerických zdrojů lingvistických (Chomsky) a z některých částí symbolick ého interakcionismu. Jak naznačuje název tohoto směru etnometodologie, jde o vědomě koncipovaný metodologický program, jak zkoumat metodicky všechny interpretace a významy, jimiž účastníci interakce v životním, každodenním světě konstruují, udržují nebo modifikují sociální realitu jako skutečnost převážně intersubjektivní. V této souvislosti etnometodologové rozvinuli celou řadu specifických ,etnometod“ pro zkoumání interakce v životním světě. Jde o takzvanou dokumentární metodu Garfinkela, o jeho specifické experimenty rozbíjení navyklých a neuvědomovaných schémat interpretace reality, o analýzu jazyka, komunikace, gest, o metodologii indexikality jako př́stupu, který zkoumá interakci kontextu všech specifických indexikálních výrazů situace, o zkoumání rozdílu mezi základními a skrytými pravidly interakce a povrchovými pravidly chování (Cicourel), o vysloveně subjektivizující pojetí sociální reality. U některých představitelů etnometodologie je koncepce sociální reality jako intersubjektivity dovedena do krajnosti idealistického pojetí. Neuznává se objektivní ráz sociální reality. Ta je objektivní v důsledku aktivit a interpretací účastníků životního světa, je objektivní, dokud ji za objektivní považují a jako objektivní ji svými interpretacemi nadále udržují. Odtud také až krajní závěry některých etnometodologů o nemožnosti zajistit objektivní vědecké poznání, protože ani metody, které jsou nutné podle etnometodologie, nejsou s to objektivní vědecké poznání zajistit. Kritická analýza předností a nedostatků etnometodologie a její metodologické výzbroje by si vyžádala další rozsáhlé studie, které autor připravuje v návaznosti na předcházející text. ${ }^{14}$ )

Americká buržoazní sociologie nemůže být kriticky analyzována ve zjednodušeném a ochuzujícím pojetí jen jako vývoj empirické výzkumné sociologie a rozvoj teoretického strukturního funkcionalismu $\mathrm{v}$ období od třicátých do šedesátých let 20 . století. Vedle a proti nim se již od třicátých let rozvíjí specifický sociálně psychologický a sociologický směr, který dostal po druhé světové

\footnotetext{
13) Viz P. Berger, T. Luckmann: The Social Construction of Reality. New York 1967.

14) Pro informaci o původních zdrojích etnometodologie viz A. Cicourel: Method and Measurement in Sociology. New York 1966; H. Garfinkel: Studies in Ethnometodology. Englewood Cliffs New Jersey 1967; J. Douglas: Understanding Everyday Life. Londýn 1971; Arbeitsgruppe Bielefelder Soziologen (Hrsg). Alltagswissen, Interaktion und gesellschaftliche Wirklichkeit, 2 Bde. Reinbek bei Hamburg 1973 .
} 
válce od H. Blumera název symbolický interakcionismus. Od poloviny šedesátých let se výrazně rozvíjí a začíná působit vlivná americká fenomenologická sociologie, která je $\mathrm{v}$ sedmdesátých letech $\mathrm{v}$ podstatě nejvlivnějším teoretickým směrem americké buržoazní sociologie s vlivem v Anglii i v Západním Německu.

Představitelé symbolického interakcionismu a fenomenologické sociologie podrobili př́śsé a dokonce i přesvědčivé kritice metodologickou a teoretickou výzbroj empirické sociologie, behaviorismu, pozitivistické sociologie i strukturního funkcionalismu. Současně rozvinuli řadu svých vlastních specifických metodologických a teoretických prrístupů, které mají značný vliv. V určité míře a určité proporci navázali (zvláště představitelé symbolického interakcionalis$\mathrm{mu}$ ) - na některé podněty skryté $\mathrm{v}$ rámci americké pragmatické filozofie, která jako určitá varianta idealistické filozofie pod vlivem německé idealistické filozofie nadhodila nebo zkresleně i řešila řadu metodologických i teoretických problémů. Vliv německé filozofie byl ještě posilněn tím, že většina představitelů pragmatismu studovala př́mo v Německu. Silné stránky německé idealistické filozofie (dialektika, důraz na činnou subjektivní stránku) se odrazily v pragmatismu i v symbolickém interakcionismu. Byly a do určité míry jsou i dnes relativně progresívní $\mathrm{v}$ americkém sociálním kontextu, kde chybí solidní tradice materialistické dialektické filozofie a kde i dnes je vliv marxisticko-leninské teorie relativně slabý.

V. I. Thomas a G. H. Mead rozpracovali řadu metodologických a teoretických podnětů včetně kritiky empirismu, behaviorismu, novopozitivistických koncepcí. Jde o zdůraznění biografického přístupu, studia osobních dokumentů, o akcent na významovou a symbolickou stránku sociální činnosti, o prvky dialektických subjekt-objektových přístupů při analýze vztahů osobnosti a společnosti. J sou to dále koncepce definice situace, teorie sociální role s dialektickými prvky, včetně teorie sociálního já a sociální osobnosti. $V$ této linii pokračoval H. Blumer, který shrnul metodologické přístupy v základní tezi o závislosti metody poznání na poznávaném sociálním objektu. Blumer rozpracoval i své pojetí metody explorace a inspekce, které mají své silné stránky zvláště v kritice empirismu, behaviorismu, pozitivismu a strukturního funkcionalismu.

Společným nedostatkem metodologických a teoretických př́stupů Thomase, Meada a Blumera je krajní psychologismus, nedostatek konkrétní sociologické, sociálně třídní a historické analýzy s prvky formalismu a abstraktního pojetí společnosti.

A. Schütz přenesl na americkou půdu metodologické a teoretické podněty husserlovské filozofie s prvky weberovské koncepce ideálních typů a studia významové a smysluplné problematiky sociální činnosti. Jeho metodologické koncepce ideálních typů, postuláty subjektivní interpretace smyslu a adekvát- 
nosti konstrukcí společenských věd jako konstrukcí druhého stupně byly významným podkladem formování americké buržoazní fenomenologické sociologie. I ta má své silné stránky v kritice empirismu, behaviorismu a neopozitivismu, naturalistického objektivismu. Přispěl k rozvinutí sociologické orientace na studium životního světa, každodennosti, běžného vědomí i interpretací, jimiž účastníci interakce vykládají své jednání. Pojem intersubjektivity pomohl nastolit otázku o podstatě sociální reality, i když s akcentem na idealistický výklad role vědomí a aktivity subjektu při konstituování sociálních významů. ${ }^{15}$ )

Ale i pro Schütze je dosti př́iznačný společný nedostatek hlavních představitelů symbolického interakcionismu - prvky abstrakního, nehistorického a netrrídního př́stupu k sociální realitě. Navíc je možné Schützovi vytknout tu vadu, že jeho metodologické a teoretické výchozí teze nejsou aplikovány ve výzkumu (až na malé výjimky pokusů o analýzu problematiky cizince, nebo sociální distribuce vědění, které mají ráz aplikace výchozích principů a metod).

Metodologické a teoretické principy Schützovy rozvinuli, převzali a selektivně použili jeho stoupenci v různých variantách fenomenologické sociologie. Ti vycházeli i z domácích filozofických a sociologických i filologických zdrojů. Nejrozšířenější je etnometodologie, která rozpracovala rozvíjením Schützových podnětů řadu metodologických principů a současně její představitelé přešli i k aplikaci své metodologie na zkoumání konkrétních sociálních jevů (výzkum delikvence, chování porotců, analýza sebevražednosti, analýza komunikace a interpretace ve skupině, nahrávky diskusí, ,garfinkelovské“ experimenty aj.). Kritické zhodnocení etnometodologie je vzhledem k jejímu značnému vlivu v USA i v Anglii a Západním Německu důležitým úkolem marxisticko-leninské sociologie. Zvláště potřebné je kritické metodologické a teoretické zhodnocení v souvislosti s danou vývojovou etapou americké sociologie, ale také konkrétní soudobé kapitalistické společnosti v USA.

$\left.{ }^{15}\right)$ Kritické zhodnocení předností a slabin fenomenologické sociologie viz především v předmluvě L. G. Jonina a G. V. Osipova k ruskému překladu knihy anglických fenomenologických sociologů P. Filmer, M. Phillipson, D. Silverman a D. Walsh: Novyje napravlenija v sociologičeskoj těorii. Moskva 1978; dále v kritickém pojednání L. G. Jonina o fenomenologické sociologii v knize L. G. Jonin, G. V. Osipov: Kritika sovremennoj buržoaznoj teoretičeskoj sociologii. Moskva 1977, s. 95-141. Pokus o stručné sociálně historické začlenění americké fenomenologické sociologie viz v E. Urbánek: Fenomenologická sociologie - vlivný směr americké buržoazní sociologie. Sociologický časopis, 1981, 1, s. 35-50. 


\section{КРИТИЧЕСКИЙ АНАЛИЗ МЕТОДОЛОГИЧЕСКИХ КОНЦЕПЦИЙ СИМВОЛИЧЕСКОГО ИНТЕРАКЦИОНИЗМА И ФЕНОМЕНОЛОГИЧЕСКОЙ СОЦИОЛОГИИ}

Pe 3 r $\mathrm{Me}$

Анализ методологических концепций сомволического интеракционализма и феноменологической социологии вполне оправдан. В ответ на стимулы, данные американской философией прагматизма символический интеракционизм развил ряд методологических стимулов, подчеркивающих определенные элементы диалектики и взаимоотношения субъект - объект при анализе взаимоотношений личности и общества, установок, ценностей и значений, а также при разработке теории роли и социального я. Крупнейшими представителями этого направления являются У. И. Томас и Д. Г. Мицд. Для них характерны акцентирование биографического подхода иметод изучения личных документов. После них Х. Блюмер развил и систематизировал концелцию символического интеракционизма, подчеркнул методическое значение реальности и ее характера для использования методов исследования. Он сам обосновал методический подход эксплорации и инспекции. Положительным у Томаса, Мида и Блюмера является ктитика бихевиоризма, эмпиризма, позитивизма и натуралистического редукционизма. Слабыми местами являются: преобладание социально-психологического подхода, недостаток конкретного социологического анализа, элементы формализма и абстрактности, неисторичный и неклассовый подход. Однако в рамках американского общества и в рамках американских общественных наук имелись определенные элементы диалектики, а подчеркивание значения «деятельной стороны» прогрессивно и имеет и сегодня определенное положительное значение

Методологические стимулы феноменологии Гуссерля для возможного развития социологической проблематики в США опосредовал А. Шютц. Он скомбинировал методологию Гуссердя - понятия жизненный мир, повседневный мир и естественная установка понятие значения и его становления, концепцию интерсубъективизма - с методологией идеальных типов, с конструкциями кукол или гомункулусов и с понятием общественных наук как дисциплин, образующих конструкции второй ступени. Он распространял постулат интерпретации субъективного смыслаповедения и постулат адекватности конструкций науки с интерпретациями представителей жизненного мира. Шютц использовал стимулы символического интеракционизма, ставшего связующим звеном в развитии феноменологической социологии в США в шестидесятые годы. Методологические принципы Шютца стали основой для развития различных направлений и вариантов феноменологической социологии в США. Самым важным и самым распространенным является этнометодолотия, выдвинувшая ряд этнометодов для анализа взаимодействия в жизненном мире и для понимания значения и смысла интерпретаций, которыми актеры создают и поддерживают социальную действительность

Шютца можно упрекнуть в формальности, абстракности, в неисторичности и бесклассовости подхода, однако положительной чертой его учения является критика слабостей эмпиризма, позитивизма и натуралистического редукционизма в общественных науках и в социологии. Анализметодологического вооружения этнометодологии и других направлений в феноменологической социологии, на которые оказал влияние Шютц, необходим уже по той причине, что их влияние очень сильно и выходит за границы США (распространены в Англии и в Западной Германии). Развитие символического интеракционизма и феноменологической социологии в США и других капитали. тических стран показывает, как сложны и извилисты пути постановки и решения воплне оправданных методологических и теоретических проблем. В США, где традиция диалектического материалистического мышления очень слаба и где марксистско-ленинская теория продолжает оставаться относительно мало распространенной и оказывает очень небольшое влияние на социологию, некоторые стимулы элементов идеалистической диалектики, содержащихся в источниках символического интеракционизма (философии прагматизма) или в феноменологической социологии (инспирации ло Гуссерлю и Шютцу) представляют собой довольно прогрессивное явление и стимулируют развитие социологического мышления и прежде всего социологические исследования. Кроме того, они являются стымулирующими для критики слабых мест других направлений и школ буржуазной социологии. 


\title{
KRITISCHE ANALYSE DER METHODOLOGISCHEN KONZEPTION DES SYMBOLISCHEN INTERAKTIONISMUS UND DER PHÄNOMENOLOGISCHEN SOZIOLOGIE
}

\author{
Zus a m m e f a s u n g
}

Die Analyse der methologischen Konzeptionen des symbolischen Interaktionismus und der phänomenologischen Soziologie hat einen trifftigen Sinn. Im Anschluß an die Anregungen der amerikanischen Philosophie des Pragmatismus entfaltete der symbolische Interaktionismus eine Reihe von methodologischen Anregungen, in denen bestimmte Elemente von Dialektik und Subjekt-ObjektVerhältnis bei der Analyse des Verhältnisses von Persönlichkeit - Gesellschaft, bei der Analyse von Einstellungen, Werten und Bedeutung auch bei Bearbeitung der Theorie der Rolle und des sozialen Ego betont werden. $\mathrm{Zu}$ den bedeutsamsten Repräsentanten dieser Linie zählen W. I. Thomas und G. H. Mead. Bezeichnend ist für sie auch die Betonung eines biographischen Herantretens an die Materie sowie die Methode, mit der persönliche Dokumente erforscht werden. In ihren Spuren ging $\mathrm{H}$. Blumer, in dem er die Konzeption des symbolischen Interaktionismus entfaltete un systematisierte, die Bedeutung der Realität und ihres Charakters für die Anwendung von Forschungsmethoden methodisch betonte. Selbständig begründete er die Methode der Exploration und Inspektion. Zum Vorteil dieser Methode zählt bei Thomas, Mead und Blumer die Kritik des Behaviorismus, Empirismus, Positivismus und des naturalistischen Reduktionismus. Als Nachteil sind die vorherrschenden sozial-psychischen Methoden, Mangel an konkreter soziologischer Analyse, Elemente von Formalismus und Abstraktivität, nicht historische sowie nicht klassenmäßige Einstellung zu nennen. Im Rahmen der amerikanischen Gesellschaft sowie der amerikanischen Gesellschaftswissenschaften waren jedoch bestimmte Dialektik-Elemente sowie Betonung der Bedeutung der „aktiven Seite" von progressivem Charakter und haben noch heute eine bestimmte positive Bedeutung.

In den USA wurden methodologische Anregungen der Phänomenologie Husserls für eine etwaige Entfaltung der soziologischen Problematik von A. Schütz vermittelt. Kombiniert wurden da Husserls Methodologie (so die Begriff vor Lebenswelt, Welt des Alltags und natürlicher Einstellung ferner der Begriff von Bedeutung und ihrer Konstituierung, Konzeption der Intersubjektivität) mit der Methodologie idealer Typen, mit der Konstruktion von Marionetten oder Homunkuli und mit der Auffassung der Gesellschaftswissenschaften als Disziplinen, die Konstruktionen zweiten Rangs bilden. Er bahnte den Weg auch für das Postulat der adäquaten Stellung der Konstruktionen der Wissenschaft und der der Interpretationen der an der Lebenswelt Beteiligten. Er machte sich die Anregungen des symbolischen Interaktionismus zunutze, der in den USA ein Vermittlungsglied der Entfaltung der phänomenologischen Soziologie in den sechziger Jahren wurde. Die methodologischen Verfahren von A. Schütz wurden zur Grundlage für die Entfaltung verschiedener Linien und Varianten der phänomenologischen Soziologie in der USA. Davon ist die Ethnomethodologie weitaus die wichtigste und die meistverbreitete. Sie enfaltete eine Reihe von Ethnomethoden für die Interaktionsanalyse in der Lebenswelt sowie für die Erfassung der Bedeutung und des Sinnes von Interpretationen, anhand von denen die Akteure die sozial Realität produzier.en und instandhalten.

Zu beanstanden sind bei Schütz Züge von Formalität, Abstraktivität, nicht historischer und nicht klasșenmäßiger Einstellung. Von positiver Bedeutung ist jedoch seine Kritik der Schwächen des Empirismus, Positivismus und des naturalistischen Reduktionismus in den Gesellschaftswissenschaften und in der Soziologie. Eine Analyse der methodologischen Ausrüstung der Ethnomethodologie sowie weiterer von Schütz beeinflußter Linien der phänomenologischen Soziologie ist schon aus dem Grunde nötig, da deren Einfluß schon von Bedeutung ist und selbst die USA-gren- 
zen übersteigt (verbreitet sind sie in England und in der BRD). Die Entfaltung des symbolischen Interaktionismus und der phänomenologischen Soziologie in den USA sowie in weiteren kapitalistischen Ländern weist darauf hin wie kompliziert und kurvenreich die Wege zur Aufstellung und Lösung der berechtigten methodologischen und theoretischen Probleme sind. In den USA, wo die Tradition des dialektischen materialistischen Denkens schwach ist, wo die marxistisch-leninistische Theorie auch weiterhin von relativ geringem Einfluß ist, sind einige Anregungen der Elemente der idealistischen Dialektik, in den Quellen des symbolischen Interaktionismus (Philosophie des Pragmatismus) oder in der phänomenologischen Soziologie (von Husserl und Schütz inspiriert) enthalten, als relativ progressiv und anregend für die Entfaltung der soziologischen Denkweise und der soziologischen Forschung zu betrachten. Besonders anregend sind sie für die Kritik von Schwächen anderer Richtungen und Schulen der bürgerlichen Soziologie. 